\title{
Public library as a place and breeding ground of social capital: A case of singang Library
}

\author{
Tzu-Tsen Chen ${ }^{1}$ and Hao-Ren $\mathrm{Ke}^{2}$ \\ Graduate Institute of Library and Information Studies, \\ National Taiwan Normal University, TAIWAN \\ Graduate Institute of Library and Information Studies, \\ National Taiwan Normal University, TAIWAN \\ e-mail: maggiechen@ntnu.edu.tw; \\ clavenke@ntnu.edu.tw (corresponding author)
}

\begin{abstract}
This paper aims at exploring the perceived outcomes and societal value of public libraries, particularly from the perspective of Singang Library, Taiwan. Survey questionnaires were distributed to Singang Library users, and 387 valid responses were analyzed. The result shows that Singang Library users benefit from library services in 22 areas of daily life, which were collapsed through factor analysis into four major outcome types: daily life information cultural activities, work related, and reading and learning. For analysis of how users use the library as a meeting place, this study shows that Singang Library is used as five different types of meeting place: square, a place for meeting diverse people, public sphere, joint activities and meta-meeting place. Singang Library as a meeting place contributes to breed bridging social capital among users' network, especially when the library is used as a low intensive meeting place. There are also bonding social capital characteristics among users who visit with their families. This paper also describes the relationship among library use frequency, perceived outcomes, library as a meeting place, and social capital, and the result indicates that the four variables are positively correlated.
\end{abstract}

KEYWORDS: Performance measurement; Perceived outcomes; Library as a place; Social capital.

\section{INTRODUCTION}

Public libraries are under the pressure of three trends: the digitalized society, forming globalization and multicultural society, and the changing of politics and ideology (Evjen and Audunson 2009). In addition to the change of worldwide trends, many countries have cut down their public library budget on account of financial crisis. As a result of these challenges, public libraries are forced to demonstrate their value to the public to earn the financial and intellectual support.

Wiegand (1999) examined research about public library value, and found that there had been a lot of studies focusing on "the user in the life of the library," but few studies concerned about "the library in the life of the user." When evaluating public library

Page | 45 
performance, researchers tend to compare the investment on resources and services, such as collection, equipment, and staff, with the outputs such as circulation and user visit counts. Though performance measurement shows the cost-benefit of public library services, it is not sufficient to reveal whether users benefit from public library services (Poll and Payne 2006).

Wiegand (2005) reviewed the role of public libraries in the last century and pointed out that public libraries had performed three things well. First, offering information on various subjects accessible for billions of people; second, furnishing reading materials for library users; and third, providing users with places to meet formally or informally. Therefore, when public libraries are required to state their societal value, only performance measurement could not show the whole picture. Researchers are encouraged to pay more attention on the library in the lives of users, which refers to the benefits that users receive from using public library services. In view of this, the purpose of this study lies in exploring the perceived outcomes and societal value of public libraries from the perspective of Singang Library, a Taiwanese public library in a countryside.

\section{LITERATURE REVIEW}

This section presents related works from three aspects: perceived outcomes of public libraries, public library as a place, and public library and social capital.

\section{Perceived Outcomes of Public Libraries}

In order to enhance the measurement of public library value, researchers, based on performance measurement, are suggested further evaluating to what extent users benefit from their experiences with public libraries, which is called outcome measurement. Outcomes, or impacts, by definition stand for the eventual result of using library services. Users are changed as a result of their interaction with public libraries (Revill 1990; Association of College and Research Libraries 1998). In other words, outcome measurement emphasizes the effect of public library on an individual or a group of users (Poll and Payne 2006).

Analysis of public library outcomes could be classified into two groups. One emphasizes on the specified outcomes and the other focuses on the general benefits. The former examines what users benefit from a particular library program and service, while the latter analyzes how library use benefits users' lives. In addition to different goals, the two groups do not share the same scope either. The specified outcomes highlight a particular library program while the scope of the general outcomes might differ from a single community to a nationwide sample (Vakkari and Serola 2012). In this paper, the general outcome of a public library in Taiwan is presented.

The general outcomes of public libraries in Finland reported by Vakkari and Serola (2012) showed that public library services benefited users most frequently in reading fiction and non-fiction, and self-education. Vakkari and Serola then clustered the 22 areas of life into three major types: benefits in everyday activities, cultural interests, and career.

After the research in Finland was published, Norway, the Netherlands, the United States, and South Korea also applied Vakkari and Serola's research to examine their public library

Page | 46 
outcomes (Vakkari et al. 2016; Vakkari et al. 2014). The cross-country study conducted by Vakkari et al. (2016) found out that users benefited most in reading, self-education, and in history and society aspects. However, different countries might have diverse results. For example, cultural activities were among the top five benefits in Finland and Norway, whereas travel and vacation were among the top five benefits in Finland, the Netherlands, and South Korea. Furthermore, their study indicated the more visits and services used, the higher the perceived benefits.

\section{Public Library as a Place}

Wiegand (2005) thought that public libraries played an important role in offering a place for people to meet formally or informally. In fact, the concept of "library as a place" could be traced back to Oldenburg (1989). In his book, the great good place: Cafes, coffee shops, bookstores, bars, hair salons, and other hangouts at the heart of a community, Oldenburg discussed about the importance of having informal meeting places, which afterwards named after "third place." The first place means home and the second place stands for work place. The third place is an informal public gathering place other than home and work place. Oldenburg observed the decline of civic participation rate and related it to the lack of informal gathering places. When people only commute between home and work place, the interaction with neighbors or the community will be reduced and limit the social network.

According to Oldenburg (1989), a third place should comprise eight characteristics. (1) A third place is on neutral ground. (2) A third place is a leveler. (3) Conversation is the main activity in a third place. (4) A third place is easy to access and offers accommodation. (5) There are regulars in a third place. (6) A third place has a low profile. (7) The mood in a third place is playful. (8) A third place is a home away from home.

The third place as an informal gathering place has multiple functions. On individual level, the third place offers the chance to meet various people and one could get inspired from their social network. Since the third place is more heterogeneous than the first and second places, it offers novelty for individuals. On social level, the third place promotes the development of democracy. Similar to Habermas' public sphere (Habermas, Lennox and Lennox 1974), the third place is the place where people could participate in public affair and discussion, sharing pinions. It is the place where people connect with each other, and build trust through interaction.

Oldenburg (2001) took Chicago Public Library as an example of the third place. However, the case of Seattle public library as a third place did not fulfill all eight characteristics that qualified a third place (Fisher et al. 2007). Another case in Norway did not fulfill all the characteristics either (Aabø and Audunson 2012). Both of the studies showed that conversation was not the main activities in public libraries and was even discouraged. Also, the public library studied did not have the regulars, who are "essential to the sustained vitality of the third place" (Oldenburg 1989). Though there were regular users in a public library, they did not share the same meaning defined by Oldenburg. The regulars in a public library tend to have private net and merely have interaction with others (Aabø and Audunson 2012). Even though previous studies showed that public libraries might not be qualified as a third place, Berndtson (2013) suggested that researchers could use the concept of the third place in the library premises when describing space and atmosphere. Furthermore, when emphasizing the importance of public libraries in the society, researchers should put the concept of third place into the context. 
Other than the lens of Oldenburg's third place, Aabø, Audunson and Vårheim (2010) brought up another perspective to investigate how public libraries were used and to what extent were used. Their research showed that public library could be used as six categories of places: as a square, as a place for meeting diverse people, as a public sphere, as a place for joint activities with friends and colleagues, as a meta-meeting place, and as a place for virtual meetings. They claimed that meeting places promoted social inclusion and the minimal degree of communality in norms, values and bridging social capital. Furthermore, meeting places, according to the extent people share common interests, could be differentiated into high-intensive and low-intensive meeting place. A high-intensive meeting place is the place where people share same interests and gather together, such as a reading club. A low-intensive meeting place is the place where people share less common interests, such as reading newspaper in the newsroom. Their study indicated that according to different community features, public libraries would be used as different types of meeting places. And the intensity of meeting places is influenced by community participation and the trust in a community institution.

\section{Public Library and Social Capital}

Social capital was first mentioned by Hanifan in 1961 (Putnam 2000). He used this term to describe goodwill, fellowship, mutual sympathy and social intercourse among individuals in a group or family. However, the research of social capital did not gain much attention that time. After Bourdieu, Coleman and Putnam published related works, studies on social capital gradually increased (Halpern 2004). According to Bourdieu (1986), social capital is the accumulation of tangible and intangible assets of an individual or a group that can be utilized to achieve the goals of the individual or group. In the library and information science field, Putnam's definition of social capital has been applied in most studies. According to Putnam (1995, p. 664), social capital comprises three indicators of social lives, social network, trust, and norms, "that enable participants to act together more effectively to pursue shared objects."

Based on the strength of a social network, social capital could be further divided into bonding social capital and bridging social capital. Bonding social capital is the strong ties that develop between relatives and friends for providing people with social support, and bridging social capital is the weak ties developing between heterogeneous people for facilitating people to access new resources (Halpern 2004; Johnson 2012; Svenden 2013). In views of trust in social capital, it could be specialized as particularized trust that people have for someone they know, and generalized trust that indicate the trust people have for general public (Uslaner 2002).

A study on public library and social capital has showed that public libraries contribute to the formation of social capital (Svendsen 2013). Johnson and Griffis (2009) concluded from their research that there was strong and consistent relationship between indicators of trust and library use. Aabø, Audunson and Vårheim (2010) brought up another perspective to investigate how public libraries were used and to what investigated public library in Norway and showed that low intensive meeting place contributed to bridging social capital. Johnson (2010) compared library users with non-users, and found that library users scored higher on community participation rate and trust. However, owing to the characteristics of the communities that public libraries served, any two public libraries might not have the same influence on social capital. A Canada study showed that public libraries in rural communities had no significant association with social capital owing that the social network in a rural community was comparatively tighter than in an urban community Page | 48 
(Johnson and Griffis 2014). In contrast with a rural community, a public library in an urban community has more influence on social capital because the latter provides relatively higher quality resources for low-income inhabitants, increasing their connection with the public library and then form the community cohesiveness. From these related studies, it shows the relationship between public libraries and social capital could be various according to different context.

\section{RESEARCH OBJECTIVE AND QUESTIONS}

Public libraries facilities and services in Taiwan, and even in Asia, have been booming in recent years. Input and output measurement are the dominating method for evaluating values of public libraries in the region; furthermore, studies on library as a place and their contribution to nurturing social capital for those libraries are rare. In view of this, this paper attempts to investigate the perceived outcomes and societal value of public libraries in the region from the perspective of Singang Library. This study aims at answering the following research questions according to the above objective:

a) What are the perceived outcomes of Singang Library?

b) To what extent Singang Library users use the library as a place?

c) How does Singang Library help users breed their social capital?

d) What are the correlations between perceived outcomes, library as a place, social capital, and library use?

Through the first research question, this study examines which of the 22 benefits proposed by Vakkari and Serola (2012) are brought by Singang Library to its users. The second question explores if the users of Singang Library use the library as a meeting place and perceive the library as a third place according to the definitions of Aabø, Audunson and Vårheim (2010) and Oldenburg (1989), respectively. The third research question investigates if Singang Library is beneficial for its users to accumulate social capital from the lens of social network, trust, and norm (Putnam, 1995).

Finally, several previous studies reveal that there are correlations between library use and social capital (Johnson 2010; Johnson and Griffis 2009), library use and library as a place (Aabø, Audunson and Vårheim 2010), library use and perceived outcomes (Vakkari et al., 2016), library use and library value (Aabø 2005), and social capital and library as a place (Aabø, Audunson and Vårheim 2010); furthermore, because library as a place is one kind of library use, it may exist correlation between library as a place and perceived outcomes.

\section{METHOD}

Singang Library is a public library in a rural community in Taiwan with a population of about 33,000 people. The data were collected through a questionnaire survey. The survey instrument comprised five sections. Section 1 collected the demographic information on the respondents, including gender, age, education, occupation, place of residence, as well as the distance from a respondent's home to the library, library use frequency and average duration of his/her stay in the library. Section 2 asked the respondents about the purposes of their visits to Singang Library and the library spaces used. Section 3 was about the perceived outcomes of the public library according to Vakkari and Serola's study (Vakkari and Serola 2012). Section 4 collected respondents' opinions on how they used Singang 
Library as a place (third place or meeting place), and Section 5 is concerned with how Singang Library helped respondents breed social capital. Three experts reviewed the questionnaire items for content validity. Thirty (30) pre-test responses were collected with Cronbach's $\alpha$ value larger than 0.7. Then the formal questionnaires were distributed to the users when they visited Singang Library during May to June 2014. Four hundred and eighty-six (486) responses were collected and 387 of them were valid. The valid responses were then analyzed through descriptive statistics, factor analysis, and logistic regression analysis by SPSS 22.0. The Cronbach's $\alpha$ values of the constructs on perceived outcomes, library as a place, and social capital are all larger than 0.7, as shown in Table 1.

Table 1: Cronbach's $\alpha$ Values of the Questionnaire Survey

\begin{tabular}{l|l||l||l}
\hline \hline \multicolumn{2}{c||}{ Constructs (Variables) } & Items & Cronbach's $\alpha$ \\
\hline \hline Perceived Outcomes & 22 benefits & 22 & 0.94 \\
\hline \hline Library as a Place & Meeting types & 8 & 0.74 \\
\hline \hline \multirow{4}{*}{ Social Capital } & Social networks & 10 & 0.84 \\
\cline { 2 - 4 } & Norm & 5 & 0.86 \\
\cline { 2 - 4 } & Trust & 7 & 0.86 \\
\hline \hline
\end{tabular}

\section{RESULTS AND DISCUSSIONS}

The analysis of the questionnaires is presented in four aspects, demographic information and library use, perceive outcomes of Singang Library, the library as a place, and the social capital among the library, in order to answer the research questions.

\section{Demographic Information and Library Use}

Singang Library has more female users (61.8 percent) than male (38.2 percent), which is similar to several public library studies (State Library of New South Wales 2000; Leckie and Hopkins 2002; Vakkari and Serola 2012). Most of the respondents aged between 7 to 14 years old (38.8 percent), and followed by 25 to 44 years old group (26.1 percent). As Singang Library is located in a countryside, it is not surprising that the respondents with age more than 55 years old were very rare (1.6 percent). About 57.6 percent of the respondents were students, 12.4 percent were teachers or civil servants, and the occupations of 9.1 percent of the respondents were related to the industry, production, and construction. About three quarters (75.1 percent) lived in the Singang Township and 73.0 percent could reach Singang Library within 15 minutes, which implies that Singang Library is accessible to most of its users.

Regarding library use frequency, 26.6 percent of the respondents visited the library one to three times per month; 22 percent visited the library one to two times per week; 8.1 percent were the heaviest users, who visited the library more than three times per week. About average duration of a user's stay in the library, 32.7 percent stayed at the library within 0.5 to 1 hour, 27.8 percent one to two hours, and 16.7 percent two to four hours.

The top five purposes of the users' visits to Singang Library (multiple choices) were borrowing and returning books (47.8 percent), self-study (33.6 percent), looking for information (31.5 percent), leisure and relaxing (30.0 percent), and reading/listening to/watching library materials ( 24.8 percent). This finding is consistent with the findings of

Page | 50 
Leckie and Hopkins (2002), and State Library of New South Wales (2000).

This study is interested in whether the users of Singang Library visited the library alone or not. The responses revealed that 62.2 percent of the respondents might visit Singang Library with their family members and/or relatives; 37.8 percent might visit the library alone; 35.7 percent and 32.0 percent might visit the library with their friends, and classmates/colleagues, respectively. This finding is somewhat different from the findings of Fisher et al. (2007), Leckie and Hopkins (2002), and State Library of New South Wales (2000), as all of their studies indicated most users went to libraries alone.

\section{Perceived Outcomes of Singang Library}

Most of the library users perceived the library as an importance place, and 81.1 percent stated that their life would be affected without the library. To further analyze how Singang Library influenced their lives, this study applied the 22 areas proposed by Vakkari and Serola (2012). Respondents were asked to rate the 22 areas that Singang Library benefited them. Figure 1 indicates that the top five aspects were educational opportunities (87.3 percent), self-education (82.4 percent), reading non-fiction (77.5 percent), reading fiction (71.1 percent), and interest in nature (68.1 percent). Similar to the cross-country study conducted by Vakkari et al. (2016), Singang Library users benefited most in reading and self-education; like South Korea and USA, educational opportunities were among the top five benefits; however, interest in nature (outdoor activities) was not among the five most popular benefits in their study.

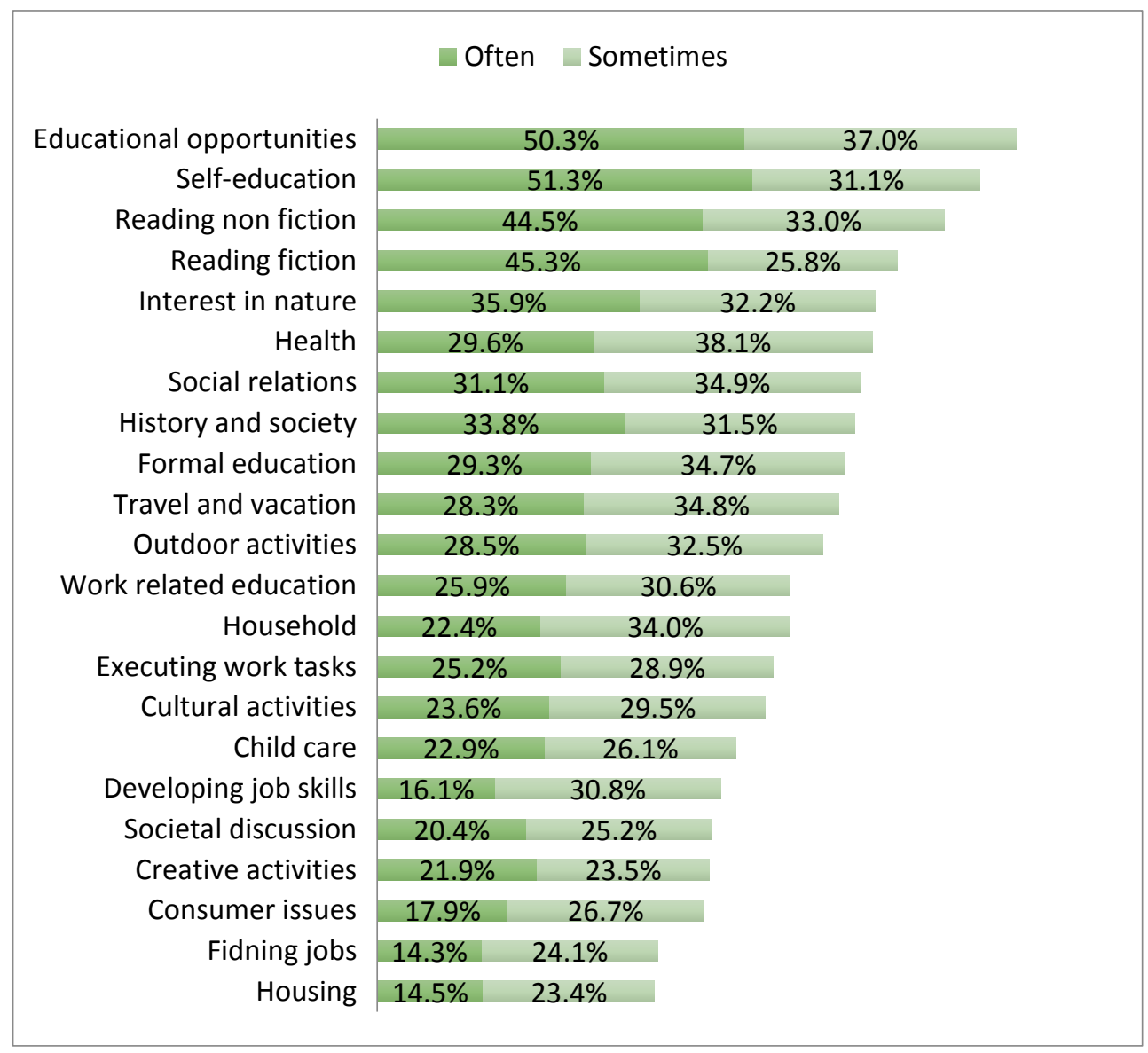

Figure 1: Perceived Outcomes of Singang Library 
The benefits in the 22 areas of daily life were then clustered through factor analysis, as shown in Table 2. The four factors indicate the most common outcome types that respondents benefited from Singang Library, and explain 65.51 percent of the variance of all variables. The four factors are called benefits in daily life information, cultural activities, work related, and reading and learning, and each of them explained 20.09 percent, 18.73 percent, 14.53 percent, and 12.14 percent of the variance of all variables, respectively.

Table 2: Four Major Outcome Types of the 22 Areas of Daily Life

\begin{tabular}{|c|c|c|c|c|}
\hline & $\begin{array}{r}\text { Daily Life } \\
\text { information }\end{array}$ & $\begin{array}{r}\text { Cultural } \\
\text { activities }\end{array}$ & Work related & $\begin{array}{r}\text { Reading and } \\
\text { learning }\end{array}$ \\
\hline Consumer issues & .81 & .21 & .26 & .10 \\
\hline Household & .72 & .24 & .36 & -.00 \\
\hline Health & .72 & .21 & .13 & .35 \\
\hline Travel and vacation & .71 & .21 & .17 & .33 \\
\hline Child care & .71 & .14 & .38 & .02 \\
\hline Household & .68 & .28 & .30 & .09 \\
\hline Social relations & .52 & .32 & .16 & .34 \\
\hline Outdoor activities & .15 & .81 & .26 & .17 \\
\hline Creative activities & .22 & .80 & .08 & .13 \\
\hline Cultural activities & .15 & .77 & .09 & .27 \\
\hline Interest in nature & .24 & .74 & .20 & .26 \\
\hline History and society & .31 & .68 & .21 & .34 \\
\hline Societal discussion & .35 & .66 & .26 & .16 \\
\hline Executing work tasks & .22 & .15 & .73 & .21 \\
\hline Developing job skills & .40 & .21 & .72 & .07 \\
\hline Finding jobs & .39 & .16 & .72 & .07 \\
\hline Work related education & .22 & .18 & .66 & .20 \\
\hline Formal education & .22 & .24 & .44 & .41 \\
\hline Reading non fiction & .24 & .26 & .01 & .70 \\
\hline Educational opportunities & .07 & .16 & .35 & .64 \\
\hline Reading fiction & .01 & .26 & -.00 & .62 \\
\hline Self-education & .19 & .12 & .31 & .61 \\
\hline Rotation & 4.42 & 4.12 & 3.19 & 2.67 \\
\hline$\%$ of Variance & 20.09 & 18.73 & 14.53 & 12.14 \\
\hline $\begin{array}{l}\text { Squared } \\
\text { Loadings }\end{array}$ & 20.09 & 38.83 & 53.36 & 65.51 \\
\hline
\end{tabular}

\section{Public Library as a Third Place}

This study examined Singang Library as a third place through Oldenburg's definition. The respondents rated by using five level Likert Scale, 5 for strongly agree and 1 for strongly disagree. Table 3 indicates that Singang Library users agreed that Singang Library was an important and safe place, and welcomed everybody. This qualifies Singang Library as a neutral ground and a leveler. However, even though users agreed that the atmosphere in Singang Library was playful, talking or having conversation in the library was not encouraged.

For the accessibility and accommodation, as mentioned previously, 73 percent of the respondents could reach Singang Library within 15 minutes from home. This qualifies

Page | 52 
Signage Library with an easy accessibility and accommodation. For the regulars, as stated previously, about 30 percent of the respondents visited the library at least once per week, and they could be called regular users of Singang Library; nevertheless, they are not in the same meaning along with Oldenburg's. The regular users in Singang Library do not play as a host in the library. They tend to enjoy themselves and do not have much conversation with others. The analysis shows that 62.2 percent of users visited the library with their family members, indicating that library is an extension of their home. Table 4 shows that Singang Library qualified 5 out of 8 characteristics suggested by Oldenburg.

Table 3: Respondents' Agreement of Singang Library as a Third Place

\begin{tabular}{lcc}
\hline \hline Characteristics & Mean & SD \\
\hline \hline Singang Library is one of the important public places & 4.33 & .75 \\
\hline \hline Singang Library is a safe place for multiple values & 4.26 & .73 \\
\hline \hline Singang Library is a place for all & 4.40 & .70 \\
\hline \hline The mood is playful in Singang Library & 4.27 & .78 \\
\hline \hline Singang Library staff are nice & 4.23 & .82 \\
\hline \hline Singang Library users are nice & 4.09 & .79 \\
\hline \hline Talking on phone in the library is acceptable & 2.51 & 1.14 \\
\hline \hline Chatting in the library is acceptable & 2.76 & 1.14 \\
\hline \hline
\end{tabular}

Table 4: Singang Library as a Third Place based on Oldenburg (1989)*

\begin{tabular}{lll}
\hline \hline \multicolumn{2}{l}{ Characteristics of a Third Place } & Singang Library \\
\hline \hline 1. & On neutral ground & Yes \\
\hline \hline 2. & A leveler & Yes \\
\hline \hline 3. & Conversation is the main activities & No \\
\hline \hline 4. & Accessibility and accommodation & Yes \\
\hline \hline 5. & The regulars & No \\
\hline \hline 6. & A low profile & -- \\
\hline \hline 7. & The mood is playful & Yes \\
\hline \hline 8. & A home away from home & Yes \\
\hline \hline
\end{tabular}

*The questionnaire did not ask whether Singang Library has a low profile.

In addition to Oldenburg's third place, this study also applied the study of Aabø, Audunson and Vårheim (2010) to examine Singang Library as a meeting place. For analysis of how users used the library as a meeting place, Table 5 shows that Singang Library might be used as five types of meeting places: square, place for meeting diverse people, public sphere, place for joint activities with friends and colleagues, and meta-meeting place. One thing to point out is that Singang Library does not provide computer and network facilities; therefore, it cannot be used for virtual meeting. Table 5 also reveals that most users used Singang Library as a low intensive meeting place (square, place for meeting diverse people, and public sphere). 
Chen, T.T. \& Ke, H.R.

Table 5: Singang Library as a Meeting Place based on Aabø, Audunson and Vårheim (2010)

\begin{tabular}{lc}
\hline Types of Meeting Place & $\begin{array}{c}\text { Users' Responses of Singang Library as a } \\
\text { Meeting Place }\end{array}$ \\
\hline \hline A square & $344(88.9 \%)$ \\
\hline \hline A place for meeting diverse people & $316(81.7 \%)$ \\
\hline \hline A public sphere & $285(73.6 \%)$ \\
\hline \hline A place for joint activities with friends and colleagues & $39(10.1 \%)$ \\
\hline \hline
\end{tabular}

\section{Public Library and Social Capital}

Putnam's definition of social capital (Putnam 1995) was adopted to analyze the social capital in Singang Library from the aspect of social network, norm and trust. Table 6 presents the survey responses. For social network, this study examined the interaction among users and library staff. The results show that many users were able to recognize other frequent users. They would also meet their friends or colleagues in the library, and some of them make new friends. Users also had good impression and interactions with library staff.

Table 6: Singang Library and Social Capital

\begin{tabular}{|c|c|c|}
\hline Social Capital Items & Mean & SD \\
\hline Social Network & 3.05 & .68 \\
\hline 1. I shall seek for help in the library when I encounter problems & 2.87 & 1.15 \\
\hline 2. I often have conversation with library staff & 2.51 & 1.13 \\
\hline 3. I often have conversation with other library users & 2.32 & 1.11 \\
\hline 4. The library is a meeting point for me and my friends & 2.54 & 1.22 \\
\hline 5. I often meet acquaintance accidentally & 2.94 & 1.13 \\
\hline 6. I can recognize other frequent library users & 2.88 & 1.16 \\
\hline 7. I often make friends in the library & 2.23 & 1.14 \\
\hline 8. The library is a place for community engagement & 3.98 & .85 \\
\hline 9. Singang Library staff are nice & 4.23 & .82 \\
\hline 10. Singang Library users are nice & 4.09 & .79 \\
\hline Norm & 2.42 & .95 \\
\hline 1. Drinking or eating in the library is acceptable & 2.58 & 1.23 \\
\hline 2. Talking on phone in the library is acceptable & 2.51 & 1.14 \\
\hline 3. Chatting in the library is acceptable & 2.76 & 1.14 \\
\hline 4. Seat occupancy in the library is acceptable & 2.35 & 1.19 \\
\hline 5. Playing in the library is acceptable & 1.89 & 1.14 \\
\hline Trust & 4.15 & .61 \\
\hline 1. I trust library staff & 4.14 & .85 \\
\hline 2. I trust library users & 3.89 & .93 \\
\hline 3. The library is one of the essential public facilities in a community & 4.33 & .75 \\
\hline 4. The library is for everyone regardless of gender, age, and social status & 4.40 & .70 \\
\hline 5. The library is a place where can hold different ideas and values from the populace & 4.27 & .82 \\
\hline 6. The library is a safe space & 4.25 & .79 \\
\hline 7. The library is a critical link for communicating between a community and governments & 3.76 & .92 \\
\hline
\end{tabular}


The analysis of trust includes particularized trust and generalized trust. The results indicate that users trusted library staff and users. Besides this, users also had trust in Singang Library as a welcoming and safe place, and even an important bridge for communication with government.

For the norm aspect, tacit library regulation is found in Singang Library, that is, users tended to share consensus that the library was a quiet place, and talking and eating was not encouraged.

Social capital could be further divided into two types: bridging social capital and bonding social capital. Both of them are found in Singang Library. For bridging social capital, Singang Library is a place for all, everyone using this place is exposed to others different from themselves. The analysis found that there are weak ties among users. Library users might not know each other, but they could identify frequent users and have general trust in them. Though they might not have verbal conversation yet, there was still invisible interaction, which encouraged them to observe the difference and respect each other.

The bonding social capital is observed among the users who visited with their family. Over half of the respondents (62.2 percent) said that they visited the library with their family members/relatives. Singang Library plays as an extension of their home and reinforces the strong tie among them. Bonding social capital would strengthen the tie among the network and might sometimes discourage the outsiders to enter. In our study, users visited with their family are found to be less likely to talk to others. In view of this, Singang Library should take actions on linking strong ties with weak ties.

\section{Correlation Analysis}

Correlation analysis was applied to analyze the relationship among the variables. The result is shown in Figure 2 . There is statistically positive correlation among variables. The meeting intensity is highly positive correlated with social network, and with the perceived outcomes as well. This result indicates that those who use the library as a meeting place will gain more benefits and nurture more social capital from the library (and vice versa). Library use frequency is also related to perceived outcomes, library as a place, and library for breeding social capital.

From this finding, Singang Library can draw up strategic planning to improve its participation in users' lives. For example, organizing activities for users visiting the library with their family members may create possibilities for them to build connections with others, which will contribute to foster bridging social capital.

\section{CONCLUSION}

Singang Library as a meeting place contributes to breed bridging social capital, especially when the library is used as low intensive meeting place. There are also bonding social capital among users who visit with their families. This paper claims the positive correlations exist among library use frequency, perceived outcomes, library as a meeting place, and library for breeding social capital. To the best of our knowledge, this is the first paper that discusses all the concepts together. 


\section{Singang Library}

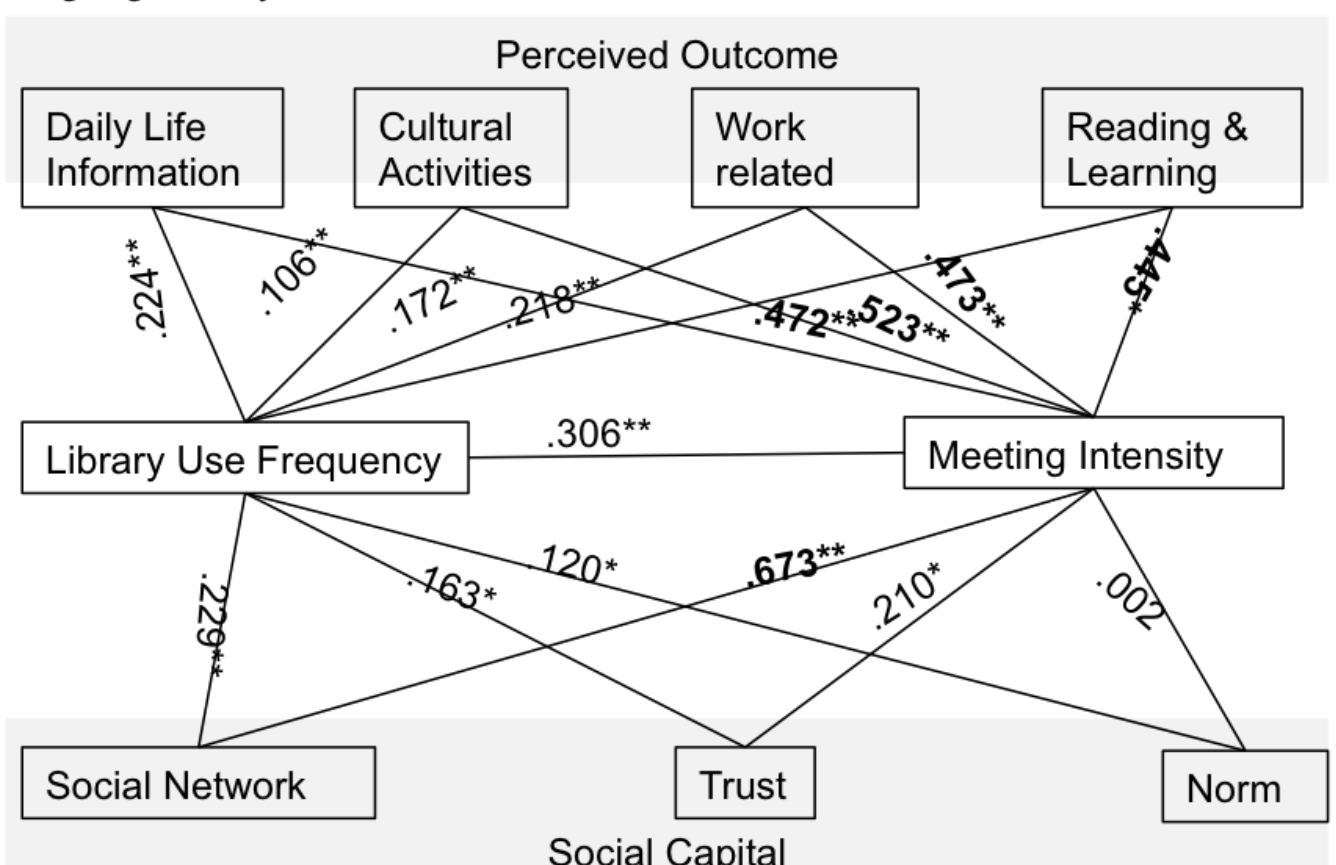

$* \mathrm{P}<0.5, * * \mathrm{P}<0.01$

Figure 2: Correlation between Perceived Outcomes, Social Capital, Library as A Place and Library Use.

Based on the results of this study, there are suggestions for Singang Library and public libraries as a whole. First, the interactions between users and library staff can be increased to strengthen the social relationship; specifically, library staff can play the role of the regulars as stated by Oldenburg, the trust among the social network can be improved and it is helpful for the library to become a third place for users. Second, organizing activities aim at users who visit with their family members in order to create possibilities for them to build connections with others, which will contribute to create bridging social capital. Third, arranging library space and services according to the purposes and needs of the users. Forth, offering better services that are frequently used and promoting services that are less used will make a public library a more important place for users.

In the era of accountability, it is essential for public libraries to show how the general public benefits from their use of public libraries. Specifically, the perceived outcomes of public libraries, how users use public libraries as a place, and how users nurture their social capital through public libraries are three aspects that a public library can use to prove its value. This study used a questionnaire survey to reveal the value of Singang Library from the abovementioned aspects. As a rural public library in Taiwan, this study may not be applicable to all public libraries in Taiwan, or public libraries in other Asian nations. In the future, the authors will expand the research to more public libraries in Taiwan, and are eager to initiate international collaboration to expand the research to public libraries in other Asian nations. Furthermore, the questionnaire survey can only tell parts of a whole story; more research methods, such as qualitative interview and observation methods, should be employed to discover the values of Singang Library.

Page $\mid 56$ 


\section{ACKNOWLEDGEMENT}

This study is financially supported by National Public Library of Information, Taiwan, R.O.C.

\section{REFERENCES}

Aabø, S. 2005. The value of public libraries: A methodological discussion and empirical study applying the contingent valuation method. Oslo: University of Oslo.

Aabø, S. and Audunson, R. 2012. Use of library space and the library as place. Library \& Information Science Research, Vol.34, no.2: 138-149.

Aabø, S., Audunson, R. and Vårheim, A. 2010. How do public libraries function as meeting places? Library \& Information Science Research, Vol.32, no.1: 16-26.

Association of College and Research Libraries (ACRL). 1998. Task force on academic library outcomes assessment report. White Paper: Value of Academic Libraries/Assessment. Available at: http://www.ala.org/acrl/publications/whitepapers/taskforceacademic.

Berndtson, M. 2013. Public libraries and placemaking. Paper presented at the IFLA World Library and Information Congress: 79th IFLA General Conference and Assembly, August 2013, at Singapore.

Bourdieu, P. 1986. The forms of capital, In: J. Richardson, eds. Handbook of Theory and Research for the Sociology of Education. New York: Greenwood: 241-258.

Evjen, S. and Audunson. R. 2009. The complex library: Do the public's attitudes represent a barrier to institutional change in public libraries? New Library World, Vol.110, no.3/4: 161-174.

Fisher, K.E., Saxton, M.L., Edwards, P.M. and Mai. J.E. 2007. Seattle public library as place: Reconceptualizing space, community, and information at the central library, In: J. E. Buschman, G. J. Leckie, eds. The library as place: History, community, and culture. Westport, CT: Libraries Unlimited: 135-160.

Habermas, J., Lennox, S. and Lennox, F. 1974. The public sphere: An encyclopedia article. New German Critique, no.3: 49-55.

Halpern, D. 2004. Social Capital. United Kingdom: Polity Press.

Johnson, C.A. 2010. Do public libraries contribute to social capital? A preliminary investigation into the relationship. Library \& Information Science Research, Vol.32: 147-155.

Johnson, C.A. 2012. How do public libraries create social capital? An analysis of interactions between library staff and patrons. Library \& Information Science Research, Vol.34: 52-62.

Johnson, C.A. and. Griffis, M.R. 2009. A place where everybody knows your name? Investigating the relationship between public libraries and social capital. Canadian Journal of Information \& Library Science, Vol. 33: 159-191.

Johnson, C.A. and. Griffis, M.R. 2014. The effect of public library use on the social capital of rural communities. Journal of Librarianship and Information Science, Vol.46, no.3: 179-190.

Leckie, G.J. and Hopkins, J. 2002. The public place of central libraries: Findings from Toronto and Vancouver. Library Quarterly, Vol.72, no.3: 326-372.

Oldenburg, R. 1989. The great good place: Cafes, coffee shops, bookstores, bars, hair salons, and other hangouts at the heart of a community. New York: Marlowe.

Oldenburg, R. 2001. Celebrating the third place: Inspiring stories about the "Great Good Places" at the heart of our communities. New York: Marlowe. 
Poll, R. and Payne, P. 2006. Impact measures for libraries and information services. Library Hi Tech, Vol.24, no.4: 547-562.

Putnam, D.R. 1995. Tuning in, tuning out: The strange disappearance of social capital in America. Political Science and Politics, Vol.28, no.4: 664-683.

Putnam, D.R. 2000. Bowling alone: The collapse and revival of American community. New York: Simon \& Schuster.

Revill, D. 1990. Performance measures for academic libraries, In: A. Kent, eds. Encyclopedia of Library and Information Science, New York: Dekker: 294-333.

State Library of New South Wales. 2000. A safe place to go: Libraries and social capital. Australia: University of Technology.

Svendsen, G.L.H. 2013. Public libraries as breeding grounds for bonding, bridging and institutional social capital. Sociologia Ruralis, Vol.53, no.1: 52-73.

Uslaner, M.E. 2002. The moral foundations of trust. United Kingdom: Cambridge University Press.

Vakkari, P. and Serola, S. 2012. Perceived outcomes of public libraries. Library and Information Science Research, Vol. 34: 37-44.

Vakkari, P., Aabø, S., Audunson, R., Huysmans, F., Kwon, N., Oomes, M and Sin, S.C. 2016. Patterns of perceived library outcomes in five countries. Journal of Documentation, Vol.72, no.2: 342-361.

Vakkari, P., Aab $\varnothing$, S., Audunson, R., Huysmans, F. and Oomes. M. 2014. Perceived outcomes of public libraries in Finland, Norway and the Netherlands. Journal of Documentation, Vol. 70, no.5: 927-944.

Wiegand, W. 1999. Tunnel vision and blind spots: What the past tells us about the present; reflections on the twentieth-century history of American librarianship. The Library Quarterly, Vol.69, no.1: 1-32.

Wiegand, W. 2005. Library as place. Paper presented the 56th Biennial Conference North Carolina Library, September 2005, at Winston-Salem, N.C, the United States. 